\title{
Anne of Kiev (c.1024-c.1075) and a reassessment of maternal power in the minority kingship of Philip I of France*
}

\author{
Emily Joan Ward \\ University of Cambridge
}

\begin{abstract}
This article is a reassessment of Anne of Kiev as mother and guardian in the early years of the minority reign of her son, Philip I of France. The available chronicle evidence is re-examined and more emphasis is given to documentary sources which have previously been disregarded or overlooked. The article addresses outdated judgements about Anne's role which are still prevalent in the historiography and aims finally to put them to rest, while arguing that Anne played a far more active role than has been suggested before.
\end{abstract}

Anne of Kiev was the only medieval princess of Rus' to travel to France for a dynastic marriage with a French king, Henry I (b. I008, sole king I03 I-60), and she became the mother of Philip I (b. IO52, sole king I060-I IO8), the longest-reigning monarch of the French kingdom since Charlemagne. However, despite her prominent status, a reassessment of Anne is long overdue in modern scholarship, especially in light of recent debate about the nature of power exercised by medieval women. ${ }^{1}$ A desire to answer the question of how power was wielded has attracted a lot of scholarship on queens and queenship in particular, ${ }^{2}$ often focusing on their role as regents or guardians. ${ }^{3}$

* This article could not have been produced without the financial support provided by the Arts and Humanities Research Council in funding the author's Ph.D. research. The author is also indebted to the support of her supervisor, Liesbeth van Houts, and is very grateful for all of her comments on earlier drafts of this work. Additional thanks go to Emmanuel College, Cambridge, and to Hazel Freestone for her comments and proofreading skills.

${ }^{1}$ For important historiography that explored, and continues to explore, the view of medieval women and power see, in particular, Aristocratic Women in Medieval France, ed. T. Evergates (Philadelphia, Pa., I999); S. M. Johns, Noblewomen, Aristocracy and Power in the 12th-Century Anglo-Norman Realm (Manchester, 2003); and The Oxford Handbook of Women and Gender in Medieval Europe, ed. J. M. Bennett and R. M. Karras (Oxford, 20I3).

${ }^{2}$ Studies on queens and queenship may be approached either through works devoted to exploring a wide timeframe, geographical area, or large number of queens; or through works which focus on one or two specific queens. Select examples from the first category are Medieval Queenship, ed. J. C. Parsons (Stroud, I994); Queens and Queenship in Medieval Europe, ed. A. J. Duggan (Woodbridge, I997); and P. Stafford, Queens, Concubines and Dowagers: the King's Wife in the Early Middle Ages (2nd edn., I998). Examples from the latter category are M. Chibnall, The Empress Matilda: Queen Consort, Queen Mother and Lady of the English (Oxford, I99I); and P. Stafford, Queen Emma and Queen Edith: Queenship and Women's Power in 11th-Century England (Oxford, I997).

${ }^{3}$ For a wide-ranging survey of women as guardians, stretching over a period of five centuries, see A. Poulet, 'Capetian women and the regency: the genesis of a vocation', in Parsons, pp. 93-I I6. However, this author would disagree with many of Poulet's statements and claims, especially those concerning Anne of Kiev herself. In addition to Poulet's study, Olivier-Martin's work explored many of the legal aspects of regency in the Capetian period, although again this focused mainly on later years (see F. Olivier-Martin, Les Régences et la majorité des rois sous les Capétiens directs et les premiers Valois (1060-1375) (Paris, I93 I)). 
Surprisingly, less research has been devoted to women who acted specifically as guardians for child kings. ${ }^{4}$ Through an understanding of women such as Anne, we are provided not only with a clearer picture of medieval queenship but also with valuable insights into child kingship - a topic which has been neglected for the central medieval period. ${ }^{5}$ This article explores Anne's role during her son's minority reign in order to reassess her position as guardian and mother. There has been no attempt to discover more about the roles Anne adopted after her first husband's death, or to critique earlier scholarship which held views we now consider to be untenable. By re-examining chronicle evidence and reviewing the documentary sources, this article will challenge the misconception that Anne played a limited role in Philip's minority and then disappeared from his guardianship in scandal. Anne of Kiev played a far more active part than has previously been appreciated and here it is hoped to address the archaic appraisals of her roles and to dispel them conclusively. ${ }^{6}$

Anne was the daughter of Yaroslav I of Kiev (c.978-I054) and Ingegerd of Sweden (c.IOOI-IO5O) and her grandfather was Vladimir I of Kiev. Her exact birth date is unknown and the best estimates have still only succeeded in narrowing it down to sometime between I024 and I032. Her family was a large one since she had at least eight siblings, many of whom married into other aristocratic families across Europe (see appendix one). ${ }^{7}$ In I05I Anne was married to Henry I of France who, two years earlier, had sent an envoy from his kingdom to seek a second marriage with one of Yaroslav's daughters. ${ }^{8}$ Such a dynastic marriage with a Rusian princess was unique. Why, then, did Henry turn to Kiev to find a wife? ${ }^{9}$ If it was simply to avoid the accusation of consanguinity with his future spouse, surely he did not need to go this far? ${ }^{10}$ A number of other reasons have been suggested. Yaroslav had previously, in IO43, proposed a marriage alliance between Henry III, the German emperor, and one of his daughters,

\footnotetext{
4 Women who acted as guardians were almost exclusively the mothers, or grandmothers, of child kings. The historiography which has discussed such women is more extensive for the early medieval period (see, e.g., P. Stafford, 'Sons and mothers: family politics in the early middle ages', in Medieval Women: Essays Presented to Rosalind M. T. Hill on the Occasion of her 7oth Birthday, ed. D. Baker (Oxford, I978), pp. 79-Ioo; J. L. Nelson, 'Queens as Jezebels: Brunhild and Balthild in Merovingian history', in Baker, pp. 3 I-77 (repr. in Politics and Ritual in Early Medieval Europe, ed. J. L. Nelson (I986), pp. I-48); R. Collins, 'Queens-dowager and queens-regent in Ioth-century León and Navarre', in Parsons, pp. 79-92).

5 The author's current Ph.D. research on 'Child kingship in England, Scotland, France and Germany, c.I050-c.I250' (forthcoming) approaches this under-represented topic in more detail.

6 The words 'guardian' and 'guardianship' will be used throughout this article since the terminology of 'regent' and 'regency' is not prevalent in the contemporary sources and conjures up early modern connotations which are inappropriate for describing the situation in I Ith-century Capetian France.

7 For a fuller discussion of the marriages of Yaroslav's daughters in particular, see ch. 3 on 'Rusian dynastic marriage', in C. Raffensperger, Reimagining Europe: Kievan Rus' in the Medieval World (Cambridge, Mass., 2OI2), pp. 7I-II4.

8 W. V. Bogomoletz, 'Anna of Kiev: an enigmatic Capetian queen of the IIth century. A reassessment of biographical sources', French Hist., xix (2005), 299-323, at p. 305; and R. Hallu, Anne de Kiev, reine de France (Rome, I973), p. 59. The envoy included Roger II, bishop of Châlons-sur-Marne; Gauthier, bishop of Meaux; and Goscelin of Chauny from the royal court. All of these men often witnessed royal acts, particularly during Philip's minority.

9 The discussion here of Anne's marriage to Henry I owes much to the work done by previous studies, in particular, and most recently, that of Bogomoletz. Bogomoletz's work has clarified the biographical details of Anne's first marriage clearly and at some length; many of these details are summarized here. For a more comprehensive discussion of the marital alliance it is worth turning to Bogomoletz, pp. 303-7.

${ }^{10}$ The desire to avoid consanguinity was the sole reason given by Duby for Henry I's decision to marry a Rusian princess (see G. Duby, France in the Middle Ages, 987-1460, trans. J. Vale (Oxford, I99I), p. I I7). However, this would certainly not have been the only reason to seek a wife in Kiev.
} 
possibly even Anne herself. ${ }^{11}$ Although the German emperor declined the offer, this failed embassy may have drawn the attention of Henry I eastwards to Kievan Rus' to seek one of Yaroslav's daughters for himself in I049. The Capetian dynasty was still at a comparatively young stage and a Rusian princess who had been offered to a German emperor may have been seen as a way of legitimizing Capetian dynastic status. In addition, Casimir of Poland had recently married one of Anne's aunts, a sister to Yaroslav, and it has been suggested that Henry I's marriage to Anne was to secure a tri-fold alliance between the kingdoms of France, Poland and Rus' against the growing power of the German empire. ${ }^{12}$ Henry had initially married Matilda, a niece of Henry III of Germany who was probably the daughter of Liudolf, Markgraf von Friesland, and Gertrude of Egisheim. ${ }^{13}$ Although Matilda bore Henry a daughter, both the mother and child died shortly afterwards in I044. Henry seemed in no rush to remarry, however, since he did not send the envoy to Kiev until Io49 and his second marriage to Anne only took place in Reims cathedral on I9 May Io5I, meaning that Henry was forty-two at the time of the ceremony. ${ }^{14}$ Due to Anne's unconfirmed birth date she may have been any age between nineteen and twenty-seven at the occasion of her first marriage to the French king.

Anne quickly bore Henry three sons and a daughter. The eldest, Philip, was born in I052, just a year into the marriage. ${ }^{15}$ Robert, probably born in I054 or I055, died in childhood. A daughter, Emma, was possibly born thereafter and the youngest son, Hugh, by the end of I057. ${ }^{16}$ Philip was co-crowned alongside his father on his seventh birthday in I059, in Reims cathedral, by Archbishop Gervais (I055-67), who paid for the entire ceremony. ${ }^{17}$ When Henry died just over a year later, on 4 August I06o, Philip was left

11 E. D. Sokol, 'Anna of Rus', queen of France', New Review: a Journal of East-European History, xiii (I973), 3-I3, at pp. 6-7.

12 For further comment on the relationships between Yaroslav's family and the Polish kingdom, see R.-H. Bautier, 'Anne de Kiev, reine de France, et la politique royale au XIe siecle', Revue des Études Slaves, lvii (I985), 539-64, at p. 545. This has also been discussed in Raffensperger, pp. 86-8, and in E. M. C. van Houts, 'The writing of history and family traditions through the eyes of men and women: the Gesta Principum Polonorum', in Gallus Anonymous and his Chronicle in the Context of 12th-Century Historiography from the Perspective of the Latest Research, ed. K. Stopka (Kraków, 2010), pp. I89-203.

13 Matilda's background is rather vague and unclear, but this identification with the daughter of Liudolf and Gertrude was made in I97I and has not been challenged since (see S. de Vajay, 'Mathilde, reine de France inconnue', Journal des savants, iv (I97I), 24I-60).

${ }^{14}$ It is possible, although unlikely, that Anne might even have been Henry I's third wife. Before the marriage to his first wife, Henry had been betrothed to Matilda, the daughter of the Holy Roman Emperor, Conrad II, and Gisela of Swabia. This marriage was proposed in May I033 when Matilda was around six years old. Wipo's Life of Conrad is the only source to record this marriage as actually having taken place, but it is unlikely that it was ever more than a betrothal since Matilda died in I034 while she was still far younger than the generally accepted marital age, which was twelve years old for women.

15 For an extensive discussion of Philip's birthdate in I052, and its narrowing to the period before I Aug. in this year, see Recueil des actes de Philippe 1er, roi de France, 1059-1108, ed. M. Prou (Paris, 1908) (hereafter Prou, Recueil), pp. $\mathrm{xv}-\mathrm{xxiii}$.

16 All three sons were definitely born by I2 July I058 since they are mentioned together with Anne in one of Henry's documents, issued at Melun around this time (Catalogue des actes d'Henri Ier, roi de France (1031-60), ed. F. Soehnée (Paris, I907), no. I02, pp. I03-5; and Bogomoletz, p. 3 IO). The suggested dates here for the births of Robert and Hugh thus rely on a certain amount of biological supposition but do also follow the most recent biographical accounts of Anne, especially Hallu, pp. 78, I34. Bogomoletz, p. 307, agrees with Hallu about the birth of Hugh. Bogomoletz suggests I055 for Robert's birth date but does not mention the possibility that Henry and Anne also had a daughter, Emma.

17 A memorandum of the coronation written by Gervais of Reims after the event survives. There is a discussion of this document in Ordines Coronationis Franciae: Texts and Ordines for the Coronation of Frankish and French Kings and Queens in the Middle Ages, ed. R. A. Jackson (2 vols., Philadelphia, Pa., I995-2000), i. 2I7-32. The full Latin text can be found from p. 226. 
monarch of the French kingdom at the age of eight years old. During the greater part of Philip's years of child kingship, his paternal uncle by marriage, Count Baldwin V of Flanders (IOI2-67), acted as his guardian. The exact arrangements are still debated, but it is now virtually undisputed that King Philip I also had some form of support from his mother in the initial years of his reign. Nevertheless, the nature of Anne's involvement and the extent of her role have traditionally been downplayed, as will be contended more fully later on. Anne remained in close proximity to her son for the rest of Io6o and the whole of I06I. She remarried some time in I062 to Raoul (c.1025-I074), count of Crépy and Valois, ${ }^{18}$ after which Philip's mother and new step-father seem to have been less prominent at court for a few years. Nevertheless, Raoul and Anne both reappear as witnesses in Philip's documents later in his reign and, when Raoul died in 1074, it is likely that Anne returned more permanently to her son's court.

The first real interest in the historical figure of Anne of Kiev came with the scholarship of the nineteenth and early twentieth centuries. ${ }^{19}$ These historians were neither limited by their source material nor by their comprehension of these sources. However, despite the important groundwork undertaken during these years, early twentieth-century historians who devoted any time to Anne were limited by a refusal fully to recognize the evidence with which they were presented and to progress ideas which, for the time, would have been decidedly radical. ${ }^{20}$ Luchaire suggested in I9OI that 'la tutelle de jeune roi' had been left jointly to both Anne and Count Baldwin, but then failed to elaborate any further. Instead he, along with Prou, simply dismissed the idea of Anne sharing Philip's guardianship. ${ }^{21}$ As a result, the early twentieth-century historiography only conceded to Anne a role in her son's upbringing and companionship, not in the political governance of the kingdom. By the early nineteeneighties, a view had emerged of Anne as a figure who had an indisputably political role during the minority. ${ }^{22}$ However, this was still seen as somewhat limited and perhaps even liminal. She was dismissed in one work as simply fitting into a category of 'conventionally pious queens and dutiful wives'. ${ }^{23}$ The chronological dispersal of the acts which mentioned Anne was interpreted as only demonstrating her insignificance, visible for a few unimportant months from the end of I060 to the beginning of Io6r. Bautier even brushed aside an act which showed Anne's involvement as late as I063 by claiming

\footnotetext{
18 For a fuller discussion of Raoul IV of Valois, see D. Bates, 'Lord Sudeley's ancestors: the family of the counts of Amiens, Valois and the Vexin in France and England during the IIth century', in The Sudeleys - Lords of Toddington (Manorial Record Soc. of Great Britain, I987), pp. 34-48.

19 In particular, see A. Luchaire, Histoire de France depuis les origines jusqu'à la revolution, ii, pt. 2: les premiers Capétians (987-1137) (9 vols., Paris, I90I); Prou, Recueil; A. Fliche, Le Règne de Philippe Ier, roi de France (1060-1108) (Paris, I9I2); Olivier-Martin.

${ }^{20}$ One example of this was the failure further to explore Anne's place in the documentary evidence, even when the large number of acts witnessed by her between the years I060 and I065 was noticed. Fliche claimed, 'sans doubte, il ne faut pas attacher une trop grande importance à ces souscriptions; beaucoup de personnages très secondaires ont apposé leur signature, tandi que celle de Baudoin, comme celle d'Anne, manque très fréquemment' (Fliche, p. I6). Fliche failed to note that the documents Anne witnesses are precisely the ones from which Baldwin was absent, or to explore what this meant for the guardianship of Philip and his kingdom.

${ }^{21}$ Luchaire, ii, pt. 2, p. I67 and Prou, Recueil, p. xxxii.

22 In particular see Hallu, pp. 82-3 and J. Verhun, 'Anne de Kiev, reine de France, et le role du comte de Flandre, Baudouin V, pendant sa régence', Revue des amis du vieux Dunkerque, xiv (I982), 5-II, at p. 6. Other studies which considered Anne's role around the same time are M. Facinger, 'A study of medieval queenship: Capetian France 987-I237', Studies in Medieval and Renaissance History, v (I968), 3-48; Sokol, pp. 3-I3; Bautier, pp. 539-64; Duby, pp. I I7-8.

23 Facinger, p. 6.
} 
that the dating was unclear. ${ }^{24}$ Overall, a large proportion of the previous scholarship on Anne was written in the early twentieth century by men to whom it had either never occurred to provide a view in which women were associated with power in the medieval period, or if it had, then this simply did not concern them. ${ }^{25}$ Such a blind spot allowed historians to argue against overwhelming evidence supporting Anne's more prominent role.

The most recent works which discuss Anne have unfortunately been limited either to outlining a biographical narrative of her life or to fitting her into a pattern of Rusian dynastic marriages. ${ }^{26}$ The previous assessments of Anne's position during her son's minority have therefore not been challenged, with many unfounded myths and incorrect affirmations with regard to the queen mother's role prevailing. ${ }^{27}$ The reassessment in this article will focus on three assumptions which are misrepresented in the current historiography but are fundamental to understanding the roles that Anne played as queen and guardian: first, that Anne's role in her son's minority was merely a continuation of the one played during her husband's lifetime; second, that Anne only had a limited part - acting as queen, not as guardian for her son or for his kingdom; and, finally, that she disappeared from the position of guardian and abandoned her children in order to get remarried.

Was Anne's position in Philip's minority simply a continuation of the power she had exercised alongside her husband during his reign? Those who have suggested this previously have even claimed that there is little more to add to the tale: 'Il y a peu à dire de la reine Anne'. ${ }^{28}$ However, while Dhondt wrote off Anne's role in Henry's reign with one sentence, he failed to mention that this was in part because Anne was bearing children throughout most of the years she was married to Henry. Anne bore at least four children during the nine years before her husband's death in I060, possibly even more since there is no surviving evidence as to whether she had any miscarriages or suffered the early deaths of any children besides Robert. If we take this into account and look only at the years after Anne had given birth to her youngest son, Hugh, probably by the end of I057, we can see her marked prominence in the last few years of Henry's reign. In the acts issued by Henry, Anne's name only appears six times in roughly thirtysix documents which were produced after her marriage and survive in originals or copies. $^{29}$ These are not spread out over the nine-year period, however. Bogomoletz has already shown that the majority of the charters (all but one) in which Anne is

24 Bautier, p. 552.

25 In particular see 'Introduction', in Prou, Recueil; Fliche; and Olivier-Martin.

26 For an extensive biographical treatment of Anne, see Hallu. Hallu's work, while questionable in other areas, does provide an extended background of Rusian history from the ninth century onwards and sets out Anne's family history on both the paternal and maternal sides. In addition, the work of Bogomoletz has extended this and provides a reasonable update to Hallu's work (see also Bogomoletz, p. 300 and Raffensperger, pp. 86-8).

27 Misleading affirmations still persist, such as Anne being deliberately excluded from court for a period of four years, or that the organization of Philip's 'royal tour' during the first years of his reign can be attributed to Baldwin alone (see, e.g., Facinger, p. 4I: 'Although Baldwin of Flanders' designation as regent did not exclude Anne from her natural rights as guardian of her seven-year-old son nor from her consecrated status as queen of France, it had at least the oblique effect of declaring her incapable').

${ }^{28}$ J. Dhondt, 'Sept femmes et un trio de rois', Contributions à l'histoire économique et sociale, iii (I964-5), 35-70, at p. 58. For another similar view, see Olivier-Martin, p. 22.

29 Anne can be found in the full text of six of the acts recorded in Soehnée, Catalogue (acts IO2, pp. IO3-5; IO4, pp. I05-6; II 7, pp. I I7-2 I; I20, pp. I22-3; I23, pp. I25-6; and I25, pp. I27-9). Added to this could be one other, the Hasnon deed of 1058 , which is regarded as a fake both by Soehnée, Catalogue, p. I30, and by Bogomoletz, p. 3 I I. The details of all seven acts can also be found compiled in Bogomoletz, pp. 3 I O-I I . 
mentioned during Henry's reign date from between October I055 and the king's death in I060. He argues that this is a deliberate move by King Henry I to bring Anne to the fore as future queen mother. ${ }^{30}$ This author would agree, but believes that this can be refined even further since, of the six charters in which Anne is mentioned, five have been dated after I2 July IO58 and the sixth, which could have been issued any time between October I055 and August I060, may also date from after I058. Anne's presence in the charters of the last few years of Henry's reign, I058-60, can thus be compared to a similar period at the start of Philip's reign, the years I060-2. Of the thirteen surviving acts from these first two years of her son's minority, eleven include a mention of Anne and her involvement. ${ }^{31}$ Although Anne's position exclusively in the last year or two of Henry's reign may have been more comparable to the first couple of years of Philip's minority, overall she seems to have taken on a far more prominent role during the minority than when she was the queen consort. Nevertheless, it is possible that once her children had been born, and in her role as consort, Anne may have acted in an advisory capacity to her husband alongside the references to her in his acts. Although we have no evidence decisively to prove this for Anne, as a young girl she may have witnessed her own mother, Ingegerd of Sweden, acting as adviser to Anne's father, particularly on Scandinavian affairs. ${ }^{32}$ This could perhaps have been a personal image of queenship on which she drew to guide her own actions, and may indeed have helped to prepare Anne for a guardianship role in the early years of Philip's reign.

Consequently, it was not a direct continuation of Anne's role which was demonstrated during her son's minority but, at the very least, an augmented position. It could even be argued that the documentary evidence demonstrates an entirely new aspect to her role during the initial years of Philip's reign, since Anne is now seen to be sharing the power of ruling alongside her son, something which had not been evident during Henry's reign. The sharing of power between mother and son is demonstrated not only by Anne's presence alongside the physical body of her son, but also in the language used to describe the relationship in both chronicle and documentary sources. In the confirmation of a grant witnessed at Dreux in Io60, Anne is shown alongside her son: 'Philipus rex cum matre regina'. 33 And Philip himself claimed in an act of I06I: 'ego Philippus, filius eius, admodum parvulus, regnum unacum matre suscepissem'. 34 The use of the term 'unacum' in this charter is worthy of particular note. This phrase was also employed, either as one or as two separate words, in charters across other kingdoms and in a number of different

\footnotetext{
30 Bogomoletz, p. 3 I 2.

31 Prou, Recueil. Anne is mentioned in all the acts II-XIV inclusive (pp. 3-45), except for VII and VIII (pp. 22-7). Prou, Recueil, III does mention Anne's name but only when quoting directly from an earlier document (pp. 8-13). Prou, Recueil, I has been excluded from the total count since it is a record of Philip's coronation in I059 and as such is before his succession as sole ruler (pp. I-3).

32 Raffensperger, p. 223. Raffensperger notes that the evidence for Ingegerd's involvement in advising her husband comes from the Morkinskinna, a narrative source. It is worth pointing out that the Morkinskinna is a thirteenth-century source, issued not much earlier than I220, and as such is not contemporary evidence for Ingegerd's involvement. However, Raffensperger also claims that the Morkinskinna narrative fits with other Swedish accounts of Ingegerd. For a discussion of the Morkinskinna and its dating, see Morkinskinna: the Earliest Icelandic Chronicle of the Norwegian Kings (1030-1157), ed. and trans. T. M. Andersson and K. E. Gade (Ithaca, N.Y., 2000), p. 66.

33 Prou, Recueil, II, p. 7, mentioned again in Prou, Recueil, III, p. I2.

34 Prou, Recueil, XIII, p. 40.
} 
ways. ${ }^{35}$ However, in royal charters during this period, it seems to have been used in particular to refer to the ruling relationship between either the wives of kings and their husbands, or the mothers of kings and their sons. Yet, it was not used in any of Henry's charters in which Anne is mentioned. One charter produced by Agobert, bishop of Chartres, and witnessed at Étampes on 25 November I060, referred to Philip and Anne together under the plural of the word 'rex'. ${ }^{36}$ Anne had a measure of equality with Philip as ruler during this period of his minority despite the fact that, following her husband's death, her power came through her son. Their motherson relationship was described by Berthold of Reichenau, who was perhaps also comparing it to the contemporary situation in the German kingdom, where Agnes of Poitou was ruling alongside her son and child king Henry IV of Germany. ${ }^{37}$ The concept of mother and son sharing power and ruling together could be seen as a topos employed by medieval writers, harking back even to the most illustrious of mother-son relationships, that of Mary and the Christ Child. Yet, in the case of Anne, this topos was a reality, and such a mother-son ruling relationship had precedents in the French kingdom throughout the Merovingian and Carolingian dynasties. $^{38}$

During the initial years of Philip's minority, we may call into question Baldwin of Flanders's position as the child king's sole guardian. Of the first thirteen charters issued in Philip I's reign during the years I060 and I06I, Baldwin is only mentioned in two. ${ }^{39}$ His absence at this stage is even more significant when it is also noted who is most prominent in the documentary evidence and in closest proximity to the child king during these same years, Anne herself. It has been suggested that Anne held her power during this period as queen, not as the guardian of her son, and on a purely superficial basis it seems hard to dispute this. ${ }^{40}$ The documentary evidence refers to her unfailingly as 'matris' or 'regina', sometimes even omitting to include her name, although this omission was not unusual for women during the eleventh century. ${ }^{41}$ But should we judge Anne's role purely from the titled form by which she was addressed? Looking more closely at the documentary evidence, it is clear that Anne was present with her son

35 An example from a different kingdom, but around the same time as Philip I was on the French throne, can be seen in a letter from Pope Alexander II to the priest of the church of Saint Mary Magdalene in Verdun in I068. This letter referred to a previous privilege to the church which had been conferred by the illustrious empress Agnes together with her son Henry IV of Germany ('Agnes, illustris imperatrix una cum filio suo Henrico glorioso rege', Alexandri II Pontificis Romani Epistolae et Diplomata, in Patrologia Latina, ed. J. P. Migne (22 I vols., Paris, I844-I903), cxlvi, col. I345A <http://gateway.proquest.com/openurl?url_ver=Z39.88-2004\&res_dat=xri: pld\&rft_dat=xri:pld:ft:all:Z300I44605> [accessed 4 Feb. 20I6]).

36 'necnon etiam dominorum nostrorum piissimorum regum, Philippi scilicet et matris eius, Agnetis' (Prou, Recueil, VI, p. 20).

37 Bertholdus Augiensis, Chronicon, ed. I. S. Robinson (Monumenta Germaniae Historica, Scriptores rerum Germanicarum, nova ser. xiv, Hannover, 2003), p. I 87.

${ }^{38}$ In particular, see Nelson, Politics and Ritual, pp. I-48. For more general treatment of child kings during this earlier period, see T. Kölzer, 'Das Königtum Minderjähriger im fränkisch-deutschen Mittelalter. Eine Skizze', Historische Zeitschrift, ccli (I990), 29I-323 and T. Offergeld, Reges Pueri: das Königtum Minderjähriger im Frühen Mittelalter (Hannover, 200I).

39 The two charters in which Baldwin are mentioned are Prou, Recueil, II and III, pp. 7, I2.

40 This has been suggested by both Prou and Verhun ('C'est donc à titre de reine et non de tutrice, qu'Anne eut entrée, pour ainsi dire, dans le conseil de régence' (Prou, Recueil, p. xxxii); 'mais pendant les deux premières années de minorité de son fils, Anne agissait en souveraine, tandis que Baudouin en tuteur-régent' (Verhun, p. 7)).

41 One example of a document which refers to Anne without using her name is Prou, Recueil, IX, p. 30. Omitting the names of women is a trait which is very common in this period, both in documentary sources and in chronicles. 
almost constantly between his coronation and some point early in I063 (see appendix two). During this two and a half year period, Anne was with Philip at Dreux (Io6o, after 4 August), Paris (I060, after Dreux), Senlis (I060, after 4 August), Étampes (25 November I060), Compiègne (30 April I06I), Reims (I4 May I06I), Senlis again (27 May IO6I), Paris again (I06I, before 4 August) and finally Soissons (I063). ${ }^{42}$ Anne's physical proximity to the child king is both prominent and substantial. ${ }^{43}$ This strongly suggests that it was Anne who performed the role of guardian in the initial years of Philip's reign, whether she was referred to as such or not. In addition, if Anne was travelling this extensively with her young son over the first couple of years of his minority reign, she would probably also have played a role in his education, either in taking responsibility for selecting and supervising a tutor for him, or in personally educating Philip in the ways in which his father had run the kingdom. Indeed, it is during this period, while at Senlis, that a figure, Ingelrannus, first witnesses a charter as 'regis custodis', although he appears later in the minority as 'magister regis'. ${ }^{4}$

The lack of guardianship terms in reference to Anne in the chronicle sources is compounded by the prominence of such terms for Count Baldwin V of Flanders. Baldwin is 'marchisus regni Francorum magistratus efficitur" ${ }^{\text {'5 }}$ and 'comes Flandrie quasi interrex in regno iudicat'. ${ }^{46}$ Moreover, many of the most overt praises of Baldwin, such as the two quotations just mentioned, come from contemporary Flemish annals. Their desire to praise one of their own counts is unsurprising, but this praise could also be seen as excessive. Whether unwittingly or with deliberation, the Flemish annals succeed in virtually writing Anne of Kiev out of the story of Philip's early years as king. Despite this, Berthold of Reichenau, writing almost contemporaneously with the events in France, does provide evidence that Anne was responsible not only for the physical body of her son but also for his kingdom. Berthold writes that after King Henry died, 'filius eius adhuc puer regnum cum matre gubernandum suscepit'. ${ }^{4}$

That the responsibility of guardianship was taken on by Anne is stated explicitly in an original act previously ignored, in which Philip referred to his mother: 'in quorum tutela et nos et regnum nostrum esse decebat'. ${ }^{48}$ The wording of this act is unambiguous in that it is both the child and the kingdom over which Anne bears the guardianship responsibility. Although Anne's contemporaries at court, and in the chancellery, evidently recognized her as guardian to her son, it makes sense that the noun 'tutela', or a similar title, was used very infrequently to refer to her. The titles of 'regina' or 'mater regis' carried far more prestige and status than that of guardian. Even after Anne's remarriage, which probably took place sometime in 1062, and after which she became

42 Prou, Recueil, II-VI, IX-XII, XVI, pp. 3-2 I, 28-37, 47-9.

43 The importance of spatial proximity to the child king has also been stated for an earlier period, Merovingian France, in Nelson, Politics and Ritual, p. 8.

44 Ingelrannus appears in Prou, Recueil, IV, p. I5 as 'regis custodis', and in Prou, Recueil, XXIV, p. 69 as 'magister regis'.

45 'Annales Blandinienses', in Les Annales de Saint-Pierre de Gand et de Saint-Amand, ed. P. Grierson (Brussels, I937), p. 27.

46 'Annales Elnonenses', in Grierson, p. I 57.

47 Bertholdus Augiensis, p. I87. There is a slight addition to the second version of Berthold's text, where the author adds Philip's name to read 'filius eius Philippus adhuc puer'. This is translated as 'Henry the king of France died, and his son, who was still a boy, received the kingdom to govern it with his mother' in Eleventh-Century Germany: the Swabian Chronicles, trans. I. S. Robinson (Manchester, 2008), p. I03.

${ }^{48}$ Prou, Recueil, XIII, p. 40. The original act is in Paris, Archives Nationales, K/20, no. 2. 
less visible in the documentary evidence, when she did witness the occasional act she maintained the prominence due to her royal title. ${ }^{49}$ In a confirmation at Orléans in I065, Anne witnessed the act second only to Philip. Baldwin, who was certainly guardian at this point and had been mentioned earlier in the document alongside the child king, signed at the head of the signatures of the secular magnates. ${ }^{50}$ But his name came only after the royal signatures, an archiepiscopal signature, and those of the beneficiary and his family. The documentary sources thus demonstrate that Anne was addressed with the honour of the titles to which she was due, but this does not prevent her from having actively carried out the role of guardian.

Not only is Anne's position in the documentary sources evidence of her role as Philip's guardian, but so too are the locations of where these charters were issued. In particular it is the prominence of Senlis, where Anne held her dower lands, during the first few months of Philip's reign that is of interest. Charters issued at Senlis only occurred during the first nine months of Philip's minority, between Henry's death on 4 August I060 and 27 May I06I. No charters are issued from Senlis at any point in Henry's reign after his marriage to Anne, nor any from the rest of Philip's minority when Baldwin was clearly acting as guardian for the child. ${ }^{51}$ The importance of Senlis to the queen mother was also demonstrated by her decision to found an abbey there in honour of Saint Vincent. Although we do not know the date it was founded, the foundation charter is recorded in a document issued by Philip after Anne's death. In this Anne sets out how she was able to build the abbey 'as a gift from my goods and those which king Henry, my husband, gave me at our marriage, all of which, with the favour of my son Philip, by the grace of God king, and the counsel of all the magnates of his kingdom, I granted to be assigned to it'. ${ }^{52}$ Historians have previously been quick to comment on how closely Count Baldwin accompanied Philip during his later minority. ${ }^{53}$ Evidence of a measure of Baldwin's control over the body of the child is suggested by the fact that some of Philip's charters after I063 were even issued at towns in lands controlled by the count, such as Lille and Furnes. ${ }^{54}$ However, during the first couple of years of Philip's minority, it was not Baldwin who dictated where the child king and his court were, but Anne, as the prominence of visits to her dower lands would suggest. If the charter evidence of place can thus be linked to control of the king, and therefore a say in who had access to him, it is evident that it was Anne who held this power before I063. This could even have been the period during which she founded the abbey of Saint-Vincent. Apart from the two initial documents issued after King Henry's death on 4 August I060, which have been mentioned above, Baldwin

\footnotetext{
49 A discussion of the dating of Anne's remarriage and more details about her second husband, Raoul, and his role can be found later in this article.

50 Baldwin was mentioned with Philip as 'domno Philippo regi et domno Balduino, comiti' (Prou, Recueil, XVIII, p. 53).

51 There are only four acts issued at Senlis in the rest of Philip's reign, outside the years Io6o-2. These are Prou, Recueil, XXXIX, pp. I Io-I4, issued I 5 June Io68; Prou, Recueil, XL, pp. I I4-I7, issued I Aug. Io68; Prou, Recueil, XLIII, pp. I20-3, issued before 4 Aug. Io69; and Prou, Recueil, LXXX, pp. 202-6, issued 28 Feb. I076.

52 This translation is taken from Epistolae: Medieval Women's Letters < http://epistolae.ccnmtl.columbia.edu/ letter/II95.html> [accessed 4 Feb. 20I6]. The full text of the document can be found in Prou, Recueil, CXXX, pp. 329-3I.

53 It has even been suggested that it was Baldwin who took Philip round the tour of the royal domain at the start of his reign. For this view, see, most recently, Bogomoletz, p. 3 I 2 . However, although he appears later, from I063, there is no evidence to suggest that Baldwin was present for the royal itinerary between Aug. I060 and May I06I.

${ }^{54}$ Prou, Recueil, XVII and XXV were issued at Lille and Prou, Recueil, XXIV was issued at Furnes (see pp. 49-5I, $67-76)$.
} 
does not appear in the documentary sources until the first half of I063. This was at Paris, when Philip confirmed the foundation of a college of canons in the church of Harlebeke made by his aunt, Adela, who was the daughter of Robert II 'the Pious' of France and also Baldwin's wife. ${ }^{55}$ Later in I063, Baldwin's prominence starts to become more noticeable in the documentary sources and he is clearly identified as Philip's guardian in a document issued at Lille, where his name comes alongside the 'rex puer' ${ }^{56}$

Much of the modern assessment of Baldwin as Philip's guardian rests upon the assumption that King Henry I appointed the magnate to that position before his death, or indeed on his deathbed. Previous studies on the legal aspects of French guardianship have shown that, in the case of an anticipated minority when the king was ill and knew he might die, the choice of guardian did seem to belong uncontestably to the preceding king. ${ }^{57}$ The argument that it was Baldwin who was thus nominated was based on the assumption that the chroniclers with the most authority said this - so it must have been so. ${ }^{58}$ However, although several chronicle sources seem to suggest this version of events, these sources should not be taken entirely at face value. The majority of the chronicle sources were written many decades after the events of Philip's minority and stories of a deathbed transferral of the boy to the count do not appear until at least the eleventwenties. By reappraising these chronicle sources, a more plausible alternative can be put forward - that it was not Baldwin who was nominated on Henry's deathbed as guardian, but Anne. The earliest of the Anglo-Norman sources to record Baldwin's role in Philip's minority was William of Poitiers, writing c.I077, whose version of events does not suggest that Henry specifically nominated Baldwin as guardian. Instead, William simply records that 'the monarchy of France, with a boy king, came under the protection, command, and administration of this wisest of men'. 59 There is no clause in William's statement to date this protection to before Henry's death, and William would certainly have been writing in favour of Baldwin, who was the father of Matilda of Normandy, wife to William I of England. Hariulf of Saint-Riquier, writing c.Io9o, claimed that Philip was handed over to Baldwin, but without addressing who was responsible for arranging such a handover or clarifying a date for it. ${ }^{60}$ The eleventhcentury sources undoubtedly see Baldwin as Philip's main guardian, without even mentioning Anne, but they are not clear in respect to the precise dating of when Baldwin received the child king under his protection.

The first source to emphasize that it was King Henry himself who handed his son over to Baldwin was Hugh of Fleury, writing c.II08. ${ }^{61}$ Although it is unclear exactly

55 Baldwin reappears in the documentary evidence in Prou, Recueil, XV, pp. 45-7.

56 'coram inclito marchione Balduino et rege adhuc puero Philippo' (Prou, Recueil, XVII, p. 50).

57 'Quand le roi est mineur, le choix du régent appartient incontestablement au roi son prédécesseur' (OlivierMartin, p. I73).

58 'un chroniqueur anonyme de Saint-Benoît-sur-Loire, Hughes de Fleury, Guillaume de Jumiège, Orderic Vital' (Prou, Recueil, p. xxix).

59 'Monarchia post Franciae, cum puero monarcho, ipsius consiliosissimi uiri tutelage, dictaturae atque administrationi cessit' (William of Poitiers, Gesta Guillelmi, ed. and trans. R. H. C. Davis and M. Chibnall (Oxford, I998), pp. 32-3).

60 'Philippus adhuc puer regiae dignitatis culmine jam suscepto a patre, regendi posse et scire nondum habens, Balduino, Flandrensium comiti, custodiendus cum regno traditur' (Hariulf, Chronique de l'abbaye de Saint-Riquier, ed. F. Lot (Collection de textes pour servir à l'étude et à l'enseignement de l'histoire, xvii, Paris, I 894), pp. 234-5).

61 'Sequenti vero anno defunctus est rex sepedictus Henricus, et apud Sanctum Dyonisium tumultus, relinquens filio suo regi Philippo nondum adulto tutorem comitem Flandrensium Balduinum, virum sibi fidelissimum et honestum' (Hugh of Fleury, Modernorum Regum Francorum Actus, ed. G. H. Pertz (Monumenta Germaniae Historica, Scriptores, ix, Hannover, I85I), p. 389). 
from where this assumption may have originated, Hugh was writing a chronicle of the kings of France, ending with the death of Philip I, who had been buried in the church of Notre-Dame in Fleury in I I08. Given Hugh's focus on kings, Anne would have figured, at most, on the periphery of the author's view. Orderic Vitalis, writing probably in the first decade of the twelfth century and using William of Poitiers's work, claimed in a later redaction of the Gesta Normannorum Ducum that Philip was entrusted to Baldwin's wardship by Henry. ${ }^{62}$ However, in the same chapter, Orderic inserted an incorrect marital history for Henry I of France, claiming that Philip and his siblings were the sons of Henry's first wife, Matilda, with no mention of Anne whatsoever. ${ }^{63}$ Orderic included a passage similar to that in Gesta Normannorum Ducum in his Historia Ecclesiastica, written c.III4 - 'Sceptra Francorum Philippo filio suo qui adhuc puerilibus annis detinebatur reliquit et Balduino Flandrensium duci puerum cum regno ad tutandum commendauit' - but again he omitted Anne. ${ }^{64}$ In addition, Orderic provided the wrong date for the year of Henry's death. ${ }^{65}$ Since Orderic either deliberately left out any reference to Anne or, probably more likely, was not entirely well informed of events in the French court decades before he was writing, we cannot expect the account of who took on the role of Philip's guardian to have included a mention of Anne. Hence the emphasis placed by Orderic on Baldwin's role after Henry's death can in part be attributed to the fact that Orderic almost certainly had no knowledge of Anne. It was William of Malmesbury, writing in the eleven-twenties, who conjured up the actual deathbed scene in which Henry appointed the count in charge of the guardianship of his young son. ${ }^{66}$ Thus, except for William of Poitiers, all of these accounts were written between thirty and sixty-five years after King Henry's death. Could the later accounts perhaps have been reading more into the guardianship situation on Henry's death than was actually the case? Chroniclers writing at the end of Philip's reign, or during the reign of his son Louis, would probably barely remember the child king who came to the throne in I060. In addition, none of the sources was substantially knowledgeable about the arrangements of the French court in the ten-sixties, as they originated mainly from monastic houses outside the Île-de France. No chronicler in the eleventh or twelfth century devoted more than a few lines to discussing Henry's death and Philip's succession. If the chroniclers did recall Philip's minority, it could also have been the case that Baldwin was more prominent in their memory because he spent longer as guardian to the child king and was the one to return the reins of the kingdom to the king when he came of age. In addition, Baldwin's political role as count of Flanders and the ties of the county with English exiles before the Norman conquest, made him a more important figure for Anglo-Norman chroniclers such as Orderic Vitalis and William of Malmesbury who, as we have seen, knew very little, if anything, about Anne of Kiev.

\footnotetext{
62 'Phylippum uero filium suum in regimine Francorum heredem constituit et tutele Balduini Flandrensis satrape commendauit' (William of Jumièges, Orderic Vitalis, Robert of Torigni, Gesta Normannorum Ducum, ed. and trans. E. M. C. van Houts (2 vols., Oxford, I992-5), ii. I 52-3).

63 Gesta Normannorum Ducum, ii. I 52-3.

64 Orderic Vitalis, The Ecclesiastical History of Orderic Vitalis, ed. and trans. M. Chibnall (6 vols., Oxford, I968-80), ii. $88-9$.

65 Orderic Vitalis, ii. $88-9$, see n. I.

66 'Rex moriens Balduino comiti Flandriae tutelam admodum paruuli Philippi filii delegauit. Is erat fide et sapientia aeque mirandus, preuiridantibus membris incanus, preterea regiae sororis conubio sullimis' (William of Malmesbury, Gesta Regum Anglorum, ed. and trans. R. A. B. Mynors, R. M. Thomson and M. Winterbottom (2 vols., Oxford, I998-9), i. 436-7).
} 
Even the contemporary Flemish sources, which praise Baldwin so excessively for his guardianship of Philip, never actually express the claim that Baldwin was appointed as guardian by Henry I. Instead they simply state that Baldwin acted as guardian for Philip. The Annales Elnonenses originally only recorded Henry's death under the year I057, but a later twelfth-century hand scratched this out, moved it to the year I06I, and made an addition which combined Henry's death and Baldwin's guardianship into one sentence. ${ }^{67}$ Although the two events are mentioned in the same sentence, they are not explicitly linked together. The Annales Blandinienses similarly did not mention Baldwin's guardianship except in an insertion, probably in an eleventh-century hand, which expressly dated Baldwin's management of the kingdom to the year following Philip's accession. ${ }^{68}$ Both accounts are directly contemporaneous and are Flemish annals, so it would have been peculiar for neither source to have expressed the claim that Baldwin was chosen as guardian by Henry on his deathbed if this had indeed occurred. The Annales Blandinienses were written at Saint Peter's abbey in Ghent, a place Baldwin visited as count and where he witnessed a number of charters. ${ }^{69}$ This set of annals is particularly well informed about events concerning the Flemish comital family around this time. Immediately following the I06 I annal, the same hand records under I063 the entrance of Robert, grandson of Baldwin V, into Frisian politics. Grierson notes that these annals are 'la seule source contemporaine' to provide this date. ${ }^{70}$ In addition to the above remarks, the fact that other Flemish annals, such as the Annales Elmarenses and the Annales Formoselenses, also note the same statement as the Annales Blandinienses and date Baldwin's guardianship of Philip to I06 I not to I060, would suggest that this dating was not seen as suspicious by other monastic writers or copyists. ${ }^{71}$ The Annales Blandinienses, Annales Elmarenses and Annales Formoselenses were not derived from each other but instead probably used a single communal source which no longer exists. Grierson suggests that this source could be a continuation of the lost annals of Saint Bertin, which was certainly used for earlier ninth-century sections of the Annales Blandinienses. ${ }^{72}$ If so, this would be an interesting connection with Count Baldwin himself since he, and the comital family more widely, were benefactors of the abbey of Saint Bertin in SaintOmer. Thus the Flemish annals agree with the earlier Norman sources that Baldwin played a role as guardian and they are also in agreement that this cannot be firmly dated to before Henry's death.

Such a rethinking of the main chronicle sources for Philip's minority is in tune with the diplomatic evidence, as discussed above, and evidently disproves the traditionally accepted view that the child king was passed directly by his father into Baldwin's hands. Instead it can probably be assumed that Anne, having already been associated with the kingdom in charters from the last couple of years of her husband's rule, was the one who was given guardianship of her son at Henry I's deathbed. The words put into the young king's mouth in a charter issued in I06I, and already referred to above,

67 'I06I. Obiit Henricus rex Francorum. Henricus rex obiit, et Balduinus comes Flandrie quasi interrex in regno iudicat, salva fidelitate Philippi pueri regis' ('Annales Elnonenses', in Grierson, p. I 57). The I2th-century addition is in italics, as per Grierson's edition. Grierson notes that 'cette notice fut écrite d'abord sous I057 et plus tard grattée' (p. I 57).

68 'Annales Blandinienses', in Grierson, p. 27.

69 Diplomata Belgica Ante Annum Millesimum Centesimum Scripta, ed. M. Gysseling and A. C. F. Koch (2 vols., Brussels, I950), i. 204-9.

70 'Annales Blandinienses', in Grierson, p. 27.

71 For these other Flemish annals, see Grierson, pp. 92, I 27.

72 However, Grierson does also state that for the mid I Ith century, the sources could instead be others which are now no longer known (Grierson, pp. xv, xix). 
describe how Philip had received the kingdom as one with his mother, emphasizing the maternal control of both king and kingdom. ${ }^{73}$ However, the view of Anne as guardian for her son does not necessarily remove Baldwin of Flanders entirely from the narrative of Philip's first two years as king. Anne's role may have only ever been intended as a temporary arrangement until Baldwin had secured his comital affairs and could return to court more permanently. Or, perhaps more likely, there might have been a less-defined situation, where Baldwin travelled backwards and forwards between the court and Flanders and the two figures of count and mother acted as co-guardians for Philip. Hallu tentatively supported this version of events with his suggestion that Anne's involvement in her son's minority came by right while Baldwin's came by nomination. ${ }^{74}$ However, any further debate on the nature of collaboration between Baldwin and Anne as guardians for the young king will have to remain hypothetical until such point as new evidence is brought to light to clarify this. ${ }^{75}$

Despite the reassessment here of the role played by Anne of Kiev, it must be emphasized that her involvement as guardian was only for the first two years of Philip's minority. The way in which Anne was removed, or indeed removed herself, from her son's minority governance has been the subject of much controversy. Anne remarried, probably in the early months of I062, to Raoul, count of Crépy and Valois. Despite her earlier prominence, she seems to have disappeared for a time from the documentary sources, handing the governance of the kingdom and guardianship of her child entirely to Baldwin. However, it is worth noting here that the evidence we have for the threeyear period of Philip's minority between the end of I06I and the beginning of 1065 is very sparse. According to Prou's dating, only three charters survive from this period. ${ }^{76}$ The evidence for Anne's 'disappearance' or 'expulsion' from court not only rests primarily on the fact that she is not mentioned in two of these charters, but also involves the creation of an argument in which the one charter which does mention Anne has to be redated. ${ }^{77}$ Although the fact that Anne took less of a role in Philip's minority from I062 is clear, the evidence used to suggest her complete disappearance from court life is, at best, highly tenuous and this author would suggest that this idea should now be rejected.

The reluctance critically to assess Anne's withdrawal from a position at her son's side has almost certainly been due to a desire to present the circumstances of 1062 as scandalous and unexpected. Modern historians have barely been able to rein in their imaginations. Anne's remarriage to Raoul has been presented as 'a scandal that rocked the kingdom', with theories of bride-kidnapping being suggested, or with emphasis put on Raoul rapidly snapping up Anne as 'a great matrimonial prize'. ${ }^{78}$ The precise dating of Anne's marriage to Raoul is unknown. The most recent biographical account of Anne attempted to fix the date to sometime in I06I. ${ }^{79}$ However, not only is this contrary to most of the previous biographical accounts, which date the marriage to

\footnotetext{
73 'dum ego Philippus, filius eius, admodum parvulus, regnum unacum matre suscepissem' (Prou, Recueil, XIII, p. 40).

74 'Anne est régente par droit, Baudoin l'est par nomination' (Hallu, p. 84).

75 E.g., we have very few charters for Baldwin himself and those we do have do not help to locate or date his whereabouts during the years I060-3.

76 The three documents are Prou, Recueil, XV, XVI, XVII, pp. 45-5I, all of which Prou dated to within the year 1063 .

77 Bautier, pp. 557-8.

78 Sokol, p. 9; and Duby, p. I 17.

79 Bogomoletz, p. 3 I 4.
} 
I062, but, in addition, no supporting evidence was provided for such a redating. All the previous historiography has agreed that Anne's remarriage to Raoul took place shortly after Henry I's death, but the accusation has been made that this was perhaps disgracefully soon. Yet studies on women of similar status across other kingdoms have shown that remarrying within one to two years of a husband's death was entirely normal at this time. ${ }^{80}$ This accusation of a 'hasty' remarriage has in part fuelled the romantic, although entirely unfounded, stories of Anne being involved in a love affair with Raoul before her first husband's death and then rushing to marry the count as soon as she was free. It is true that the theory of an extra-marital affair cannot be disproved, but without any evidence to support it we should be wary of attributing a callous glee at Henry's death to his widow. Indeed, the argument in support of a quick marriage between Anne and Raoul relies heavily on the chronicle of Saint-Pierre-le-Vif, where Henry's death and Anne's remarriage are combined in one sentence. ${ }^{81}$ This would surely be scant enough evidence to support this argument even if the chronicle was a contemporary source. However, as it is, the Saint-Pierre-le-Vif chronicle was not begun until around IIO8, some fifty years after the marriage took place. ${ }^{82}$ In addition, serious flaws in the historical accuracy of the chronicle have already been revealed. ${ }^{83}$

No conclusive evidence survives for whether Anne had a choice in her new marriage. However, a letter from Archbishop Gervais of Reims to Pope Alexander II in I062 suggests that neither ecclesiastical figures, nor indeed Philip himself, had apparently agreed with the decision. ${ }^{84}$ It is therefore unlikely that any pressure to remarry came from the ecclesiastical magnates who had a place at court. Contemporary criticism of the marriage resulted from the fact that Raoul had repudiated his previous wife, an heiress called Aliénor or Hannequez, in order to marry Anne. ${ }^{85}$ This would have upset those in ecclesiastical circles, who had a responsibility to promote the sanctity of marriage, far more than the secular magnates. It certainly seems as if the letter from Gervais was written more with the ecclesiastical nature of the grievance in mind than with a concern for the well-being of the young king. Gervais's main concern in writing to Pope Alexander was to make him aware of the wrong done by Raoul and to try to achieve

${ }^{80}$ E.g., when King Æthelred (c.963-Ior6) died on 23 Apr. Ior6, his widow, Queen Emma, was married to King Cnut by Aug. IOI 7. For a discussion of Emma's two marriages and the laws around widows remarrying, see Stafford, Queen Emma and Queen Edith, p. 228. In addition, DeAragon's wider study of dowager countesses in the Anglo-Norman kingdom between I066 and I230 showed that all remarriages were within five years and that most subsequent marriages took place one to two years after the previous husband's death (see R. C. DeAragon, 'Dowager countesses, I069-I230', Anglo-Norman Stud., xvii (I995 for I994), 87-Io0, at p. 90).

81 'Mortuo autem Hainrico rege apud Vitriacum castrum in Bieria et sepulto in basilica Sancti Dionisii, Rodulfus comes, cunsanguineus eiusdem regis, duxit uxorem eius in conjugio contra jus et fas, unde fuit excommunicatus' (Chronique de Saint-Pierre-le-Vif de Sens, dite de Clarius, Chronicon Sancti Petri Vivi Senonensis, ed. R-H. Bautier and M. Gilles (Sources d'histoire médiévale, Paris, I979), pp. I24-6). For an example of an article which relies heavily on the evidence from this chronicle to support its arguments, see Bautier, p. 556.

${ }^{82}$ The editors of the most recent edition of the Chronique de Saint-Pierre-le-Vif de Sens date the second part of the chronicle, which contained the years of Philip's reign, to I I08 or I I09. For a discussion of the dating of the chronicle, see the introduction to Chronique de Saint-Pierre-le-Vif de Sens.

83 E.g., Fliche notes that the chronicler records Raoul's death in Io66 which is not only false, but is out by a period of eight years since Raoul actually died in I074. Fliche concluded that because of these inaccuracies, 'il est donc difficile d'accorder quelque autorité au témoignage du chroniqueur sénonais' (Fliche, p. 20).

84 'Regina enim nostra Comiti Radulpho nupsit, quod factum Rex noster quam maxime dolet' (Gervais de Reims, 'Gervasii Remorum Archiepiscopi, epistola ad Alexandrum II Papam', in Recueil des historiens des Gaules et de la France, ed. M. Bouquet (24 vols., Paris, I738-I904), xi. 499).

${ }^{85}$ Anne became Raoul's third wife since, before his marriage to Aliénor, he had first married Adèle, the daughter and heiress of Nocher III, count de Bar-sur-Aube. 
some form of justice for Aliénor, who had almost certainly appealed to the archbishop about her situation. ${ }^{86}$ Gervais's initial emphasis on Philip's grief about his mother's remarriage was used in order to support the case against Raoul, not a case against Anne.

A second letter, probably in response to Gervais's initial entreaty to Pope Alexander, was sent by the latter to both Gervais and the archbishop of Sens who, although unnamed in the letter, was probably Richer. ${ }^{87}$ The letter details the cause of separation between Raoul and Aliénor and asks both recipients to act as canonical judges over the case. Aliénor even visited the papal see at Rome at this point in order to put her own case before Alexander personally, since she is addressed in the letter as 'Mulier ista, praesentium litterarum portatrix'. ${ }^{88}$ The pope certainly seems to have been bothered enough about the fate of Raoul's repudiated wife to try to further Aliénor's cause. However, Alexander's concern in the letter focuses on recovering property which Raoul has taken from her and on clearing her name from the false claims of adultery. There is no surviving evidence besides the letter from Gervais to Pope Alexander to suggest that either Count Baldwin or King Philip were upset by Anne's remarriage. And it is only modern scholarship which has used, deplorably, the word abandonment in relation to Anne. ${ }^{89}$ Indeed, later medieval commentators chose instead only to praise Raoul for his marital decision, seeing it as an increase of his prestige and influence. ${ }^{90}$ Raoul was absent from the king's witness lists for a few years after I062, but whether this was due to personal choice or at someone else's request cannot be determined. Later in Philip's reign, from I065, Raoul's name returns to many of Philip's acts, most noticeably in a document witnessed by the trio of Anne, Baldwin and Raoul. ${ }^{91}$ If the marriage 'scandal' affected Raoul initially, he seems to have brushed it off relatively quickly and, in I067, William of Poitiers noted that 'the mighty Count Raoul' was present at William the Conqueror's Easter celebration at Fécamp with many other French nobles. $^{92}$

Can we therefore conclude that Anne may have had some role in picking her new husband herself? The right of consent in marriage arrangements was always maintained by the medieval church, but whether this worked in practice is questionable.

\footnotetext{
86 'De uxore vero Comitis Radulphi, quae vestrae conquesta est paternitati, se a viro injuria esse dimissam, id vobis notum esse volumus' (Recueil des Historiens des Gaules et de la France, xi. 499).

87 The letter is addressed as such: 'Alexander episcopus, servus servorum Dei, charissimo fratri Gervasio Remensi archiepiscopo omnibusque suffraganeis suis, necnon Senonensi archiepiscopo suisque suffraganeis’ (Pope Alexander II, 'XLI. Alexandri II epistola ad Gervasium Remensem et ad Senonensem', Alexandri II Pontificis Romani Epistolae et Diplomata, cols. I3 I9D-I320B). The dating of the letter is uncertain, but if it was sent before I 2 March I062, Mainard would still have been archbishop of Sens. In Apr. I062 he was succeeded by Richer and this is usually who has been credited as the addressee, e.g. when the letter was printed in Recueil des Historiens des Gaules et de la France, xiv. 539. However, perhaps the lack of a name attached to the archbishopric suggests that the letter was sent in the intervening weeks before the pope had had confirmation of who had succeeded Mainard to the see of Sens.

${ }^{88}$ Pope Alexander II, 'XLI. Alexandri II epistola ad Gervasium Remensem et ad Senonensem', Alexandri II Pontificis Romani Epistolae et Diplomata, col. I320A.

89 Bautier claims, with a distinctively negative tone, 'on peut ajouter qu'Anne abandonnait ses enfants en bas-âge ... au moment même où de nouvelles crises menaçaient' (Bautier, p. 555). This idea has even more recently been supported by Bogomoletz ('Anna had only recently been widowed and she was abandoning her two small children' (p. 3 I4)).

90 'How great he was can also be gathered from the single fact that he married the mother of King Philippe after the death of her husband' (Guibert of Nogent, Self and Society in Medieval France: the Memoirs of Abbot Guibert of Nogent, ed. J. F. Benton (New York, I970), p. 57).

91 Prou, Recueil, XVIII, p. 53.

92 Gesta Guillelmi, pp. I78-9.
} 
Nevertheless, a woman in Anne's position may have had more influence over her marriage arrangements than most other women. ${ }^{93}$ Anne was a widow with influence at the royal court, her own personal wealth and lands from her dower around Senlis, and the appealing status of queen mother. Perhaps she chose to remarry at a time and to a man of her own choosing, before she was forced into a politically suitable match over which she had less control. As a widow, Anne could have turned instead to the church if remarriage was entirely unpalatable to her. And it was not just Anne's future husband who stood to gain from the match. There were good political reasons for the queen mother to marry Raoul; namely, to keep a powerful magnate who had once rebelled against her husband on the side of her son. But we also cannot rule out personal motivations for her own security and future. Anne had lost a male protector and supporter in the form of her first husband, and her son was still young enough that he had his own worries to deal with. Her position as a foreign princess may also have been a cause of vulnerability which could have become more obvious after Henry's death, although by ro6o Anne had lived in France for nearly a decade of her life.

The figure at the centre of all Anne's actions during the years 1060-2 was her son Philip, then aged eight to ten years old. Can we understand anything from the sources regarding Anne's relationship with her son once she was no longer responsible for his guardianship? The letter sent by Archbishop Gervais to Pope Alexander, referred to above, has been used as evidence that Anne's remarriage caused excessive worry to the child king and to those who surrounded him. ${ }^{94}$ Whether or not this worry was a trope used by the ecclesiastical writer of the letter cannot be confirmed, but even if it was not, Philip's worry can only be taken as a sign of his closeness to his mother. Yet, if Philip had been upset by the remarriage, it evidently did not affect his later relationship with Anne. Even after she no longer had a role as his guardian, Anne appears to have maintained a good relationship with her son. This is demonstrated throughout Philip's adult reign, during which Anne continued to witness charters, although less regularly after 26 January I065. ${ }^{95}$ A charter was given by Philip to the church of Saint Vincent in Senlis at Anne's request in I069. ${ }^{96}$ And after his mother's death, Philip still seemed to be concerned to continue her legacy, reissuing and confirming the foundation charter of Anne's foundation of Saint-Vincent at Senlis and adding a clause of his own to the end. ${ }^{97}$

It is undeniable that Baldwin of Flanders took a more consistently prominent role as Philip's guardian than Anne. He was involved for a longer period of time, is more evident in the documentary sources, and far more manifest in the chronicles. However, the aim of this article is not to promote Anne over Baldwin; it is simply to address the lack of any detailed analysis of her role. This reassessment of Anne of Kiev has

\footnotetext{
93 See DeAragon, p. 90. DeAragon has shown that the remarriage of widowed dowager countesses in the English kingdom to men of lower social or economic status than their initial spouse, as in Anne's case, could point to the personal choice of women in their remarriage. It is hard to accept without question, therefore, that such a marriage would have been 'clearly demeaning to the royal status of Anna', as has been suggested by Bogomoletz, p. 3 I 4 .

94 Olivier-Martin claims that Anne's second marriage caused 'beaucoup d'inquiétude dans l'entourage du jeune roi' and again, later, that she inflicted 'beaucoup de peine à l'enfant roi et d'inquiétude à ceux qui le gardaient' (see Olivier-Martin, pp. 2, 25; Bogomoletz, p. 3 I 4).

95 Bogomoletz, pp. 299-323.

96 Prou, Recueil, XLIII, pp. I20-3.

97 Prou, Recueil, CXXX, pp. 329-3 I.
} 
demonstrated that new facts can still be brought to light, such as the prominence of Anne's dower lands at Senlis as her power base and how this affected the queen's choice as to where she chose to take her son when she controlled his physical body. Previously accepted statements may now be challenged by the reinterpretation of the sources. This is particularly important for dismissing the idea of Baldwin's deathbed appointment by King Henry I and for discrediting the implication that Anne 'disappeared' from power due to a scandalous remarriage. What is evident from the chronicle sources is that a process of writing Anne out of history as the guardian for her son and his kingdom did exist. Those writing contemporaneously never expressly stated Anne's role in the early years of Philip's minority, except for Berthold of Reichenau, but nor did they ever attribute a deathbed testimony to Henry in which he bestowed his child upon the count of Flanders. However, as the decades passed and Baldwin's role in Philip's minority became more widely known, those writing accounts in the first few decades of the twelfth century started to introduce this version of the story. The answer to why the chroniclers were doing this - as a deliberate exclusion of a woman in a political role, from a lack of evidence, or even subconsciously - would certainly be interesting to explore further. The possibility that some medieval chroniclers might have been deliberately playing down Anne's role has rarely, if ever, been suggested in the secondary literature. To many of the overwhelmingly monastic writers the idea of a woman sharing power with, or holding power for, a male figure would at the very least have been one which was uncomfortable, and at the most an entirely unfamiliar concept.

Finally, this author would like to add two significant reasons why this reanalysis of Anne of Kiev is so critical. If Anne did indeed exercise guardianship for her underage son, even for only two to three years as is suggested here, this makes her one of a select group of women across Europe during the central middle ages for whom it can be proven that they held this position and exercised this form of power. In north-western Europe during the period I050-I250, only two other queens undertook a similar role for sons who were under the age of fourteen when they came to the throne - Agnes of Poitou (c.I024-I077) for Henry IV of Germany and Blanche of Castile (II88-I252) for Louis IX of France. However, looking more widely across Europe, Anne may also be seen alongside a number of other royal women, such as Melisende of Jerusalem (d. I I6I), ruling for her son Baldwin III as well as in her own right; Constance of Sicily (d. I I98), the mother of Emperor Frederick II; Constance of Aragon (d. I222), Frederick's first wife and guardian of their son Henry (VII), the young king of Sicily; Margaret Sambiria (d. I282), guardian for her son Erik V of Denmark; and, although before the eleventh century, Ol'ga (d. 969), Anne's great-great-grandmother and ruler of Kiev for her son Sviatoslav. Anne of Kiev's role is thus highly significant as a comparison and contrast with these women. ${ }^{98}$ In addition, when compared to men for whom we have just as little evidence or who played a comparably short role in the political sphere of kingship, Anne's guardianship of a child king seems to have been significantly neglected and under-represented. It is hoped that this article has done something to redress this balance.

\footnotetext{
98 For a recent discussion of 'regent queens', with suggested further reading, see A. Fößel, 'The political traditions of female rulership in medieval Europe', in Bennett and Karras, pp. 68-82, at pp. 77-9.
} 
Appendix 1

Genealogy of Anne of Kiev (c.1024-c.1075)

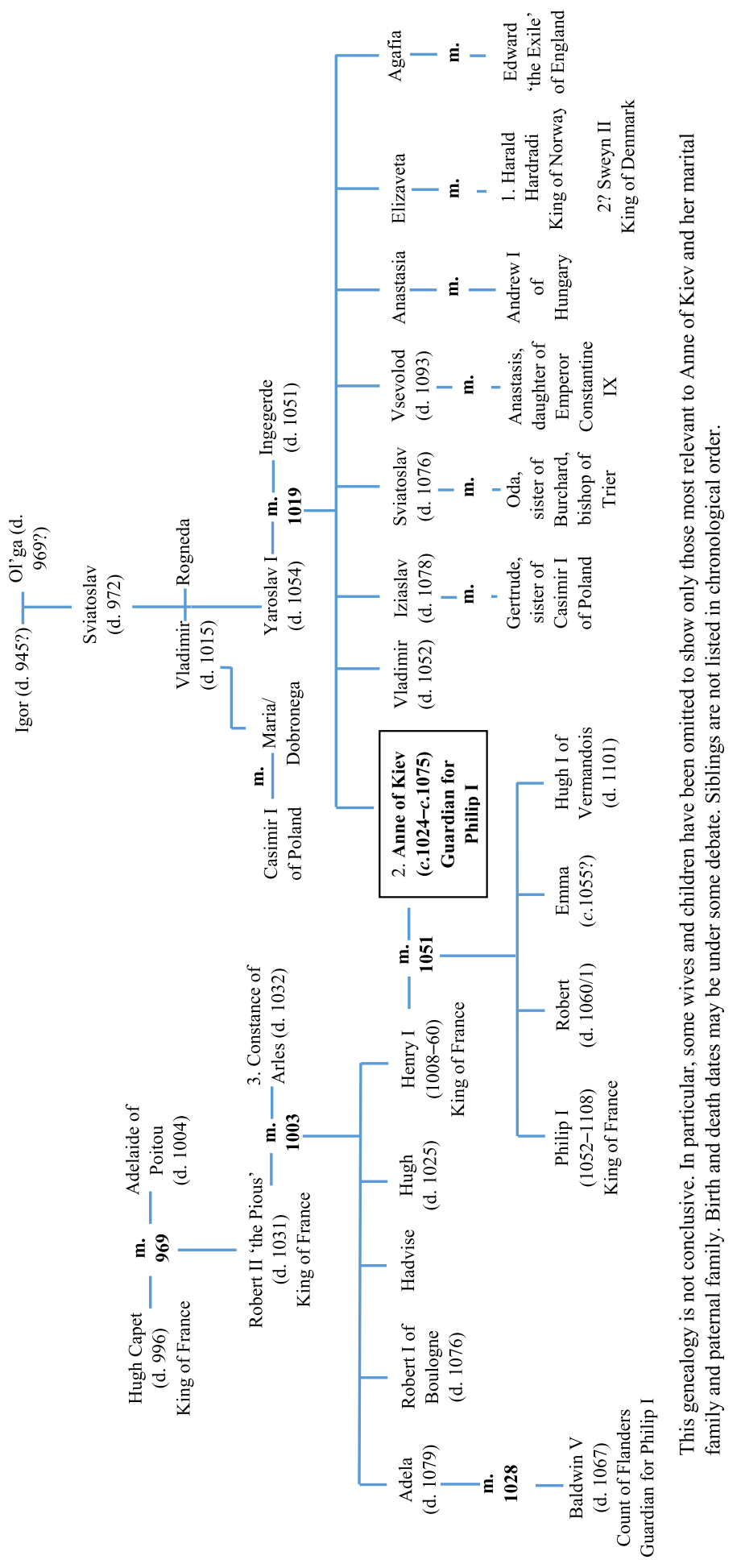




\section{Appendix 2}

Rough itinerary for Anne of Kiev, 1060-3

Based on charters and dates taken from Recueil des actes de Philippe 1er, roi de France, 1059-1108, ed. M. Prou (Paris, I908).

I060, after 4 August

I060, after Dreux

I060, after 4 August

25 November 1060

30 April I06 I

I 4 May I06I

27 May I06I

I06I, before 4 August

I063
Dreux

Paris

Senlis

Étampes

Compiègne

Reims

Senlis

Paris

Soissons 